\title{
Factors Associated With Cholinesterase Level of Spraying Workers Using Paraquat Herbicide At Oil Palm Plantation In East Kalimantan, Indonesia
}

\author{
Iwan Muhamad Ramdan ${ }^{1 *}$, Krishna Purnawan Candra ${ }^{2}$, Herry Purwanto ${ }^{3}$ \\ ${ }^{1}$ Dept.Occupational Health and Safety, Fac. Public Health, Mulawarman University, Samarinda, Indonesia, \\ ${ }^{2}$ Dept.Agricultural Product Technology, Fac. Agriculture, Mulawarman University, Samarinda, Indonesia, \\ ${ }^{3}$ Ministry of labor of the Republic of Indonesia, Health and Safety Laboratory, Samarinda, Indonesia. \\ *Corresponding Author: iwanmuhamadramdan@gmail.com
}

Info Artikel : Diterima 10 April 2019 ; Disetujui 1 Februari 2020 ; Publikasi 1 April 2020

\begin{abstract}
Background: In 2006, World Health Organization estimates a number of 1-5 million cases of pesticide poisoning per year in agricultural workers with deaths reaching of 220,000 casualties. About $80 \%$ of pesticide poisoning was reported in developing countries, including Indonesia. In the last ten years, palm oil plantation area in East Kalimantan increased at 7.7\%. In 2017, palm oil plantation covered an area of 1,2 billion ha with 234.000 workers. Until now, there is no study on pesticide exposure on health disorder with indicator using cholinesterase level.

Methods: A cross-sectional study has been conducted using simple random sampling on 326 sprayers from 10 oil palm plantations using paraquat herbicide to identify herbicide poisoning prevalence, and its risk factor. The pesticide poisoning rate was measured based on blood cholinesterase enzyme level using a Tintometer kit. Age, working period, and spraying area per day were collected by direct interview. Data were analysed by Spearman test.

Results: The most sprayer workers was at age of $>26-34$ years (31.9\%), having working experience $<5$ years (76.1\%), implementing a spray area per day of $<4$ ha (84\%). A mild toxicity was experienced by 29 sprayers (8.9\%). The prevalence of paraquat herbicide was correlated significantly with age $(p=0.000)$ and spraying area per day $(p=0.014)$.

Conclusion: The prevalence of paraquat among herbicide sprayer at oil palm plantation was relative low. Application of herbicide with lower doses and reducing the spraying area are the necessary factors to be considered in order to prevent the herbicide poisoning become worst.
\end{abstract}

Keywords: Herbicide; paraqua; cholinesterase; sprayers of oli palm plantation.

\begin{abstract}
ABSTRAK
Latar Belakang: Organisasi Kesehatan Dunia pada tahun 2006 memperkirakan 1-5 juta kasus keracunan pestisida setiap tahun pada pekerja pertanian dengan kematian mencapai 220.000 korban. Sekitar $80 \%$ keracunan pestisida dilaporkan di negara-negara berkembang, termasuk Indonesia. Pada 10 tahun terakhir, luas perkebunan kelapa sawit di Kalimantan Timur meningkat sebesar 7,7\%. Pada tahun 2017 perkebunan kelapa sawit di Kalimantan Timur mencapai 1,2 juta ha dengan jumlah pekerja mencapai 234 ribu orang. Hingga saat ini belum pernah ada kajian dampak paparan pestisida terhadap gangguan kesehatan dengan indikator kadar cholinesterase. Tujuan penelitian ini untuk menganalisis faktor yang berhubungan dengan tingkat keracunan penyemprot perkebunan kelapa sawit yang mengaplikasikan herbisida paraquat.

Metode: Penelitian cross-sectional dengan metoda sampling acak sederhana telah dilakukan pada 326 penyemprot dari 10 perkebunan kelapa sawit yang menggunakan herbisida paraquat, untuk mengidentifikasi prevalensi keracunan dan faktor risikonya. Tingkat keracunan pestisida diukur berdasarkan kadar enzim cholinesterase darah menggunakan Tintometer kit. Usia, masa kerja, dan area penyemprotan per hari dikumpulkan dengan wawancara langsung. Data dianalisis menggunakan Uji Spearman.
\end{abstract}


Hasil: Penyemprot herbisida sebagian besar berusia $>26-34$ tahun $(31,9 \%)$, mempunyai masa kerja $<5$ tahun $(76,1 \%)$, menyemprot area seluas $<4$ ha per hari $(84 \%)$. Toksisitas ringan dialami oleh 29 orang penyemprot $(8,9 \%)$. Keracunan ringan herbisida tersebut berkorelasi signifikan dengan usia $(p=0,000)$ dan area penyemprotan per hari $(p=0,014)$.

Simpulan: Prevalensi keracunan paraquat di kalangan pekerja penyemprot herbisida di perkebunan kelapa sawit relatif rendah. Penggunaan herbisida dengan dosis yang lebih rendah dan pengurangan area semprot menjadi faktor penting untuk dipertimbangkan dalam usaha pencegahan keracunan herbisida yang lebih buruk.

Kata kunci: Herbisida; paraquat; cholinesterase; penyemprot perkebunan kelapa sawit.

\section{INTRODUCTION}

Pesticides have a major role in increasing agricultural production through the prevention of losses due to pests. ${ }^{1,2}$ However, various studies have shown an association between the use of pesticides with health disorders suffered by workers such as skin, ${ }^{3}$ gastrointestinal, ${ }^{4,5,6}$ respiratory, ${ }^{7,8}$ reproductive,${ }^{9}$ and endocrine system disorders, ${ }^{10}$ as well as increased incidence of cancer, ${ }^{6,11}$ decreased cholinesterase levels, fetal abnormalities, spontaneous abortion among pregnant women. ${ }^{12}$

World Health Organization (WHO) estimates that every year there are 1-5 million cases of pesticide poisoning in agricultural workers with deaths reaching 220.000 casualties. About $80 \%$ of pesticide poisoning is reported in developing countries. ${ }^{13}$ Based on the result of cross sectional study in 1995 by Indonesian Minister of Health, reported that $60 \%$ had normal cholinesterase activity, $28.03 \%$ were mild poisoning, $7.86 \%$ medium poisoning and $1.11 \%$ severe poisoning. ${ }^{14}$

Indonesia is an agrarian country. About $42.7 \%$ of labours are in the agriculture sector, and this sector contributes about $21.52 \%$ to gross domestic product. One of the important agricultural commodities is palm oil. ${ }^{15}$ East Kalimantan is one of the largest provinces in Indonesia, in which the oil palm plantation area until 2016 has reached 1,150,078 Ha consisting of $277,034 \mathrm{Ha}$ as plasma plant (owned by the people), 14,402 Ha owned by state-owned enterprises as core and 858,642 Ha owned by Private Plantation. Total production of Fresh Fruit Bunches in 2016 was $11,418,110$ tons. The number of prominent private companies was about 344 companies with workers of 234,100 people. $^{16}$ The lower level of protection and welfare of workers is one of the labour problems in East Kalimantan. ${ }^{17}$

The government of the Republic of Indonesia has issued Act No. 6 of 1995 to protect human health, natural resources, fauna, and natural flora, which contains the basic policy that crop protection should be implemented with an integrated pest control system in which pesticide is only used as the last alternative. However, paraquat (N, N'-dimethyl-4,4'-bipyridinium dichloride) is still widely used at oil palm plantation companies. $^{18}$

There are some reports indicated that the spray workers at oil palm plantation sometimes showed poisoning prevalence or had a serum cholinesterase activity below $75 \%$ through a routine check from the Health Board of East Kalimantan Province. Incorrect spraying techniques has increased the health risks for farmers and the wider community. ${ }^{2}$ The use of the herbicides often does not pay attention to the usage instructions contained in the packaging bottles. ${ }^{19}$ Some other factors might associate with the poisoning prevalence of the spray worker.

Previous studies showed that age, sex, use of personal protective equipment, frequency and duration of exposure, the direction of spraying based on wind direction, area and time of spraying were related to the level of cholinesterase activity of spray workers. $^{20-23}$

Until now, there is no information about the impact of the use of pesticides on health of oil palm plantation workers. This study aimed to determine the factors associated with pesticide poisoning level among spray workers at oil palm plantations in East Kalimantan, who applied paraquat herbicide. This study will lead to improvement activities to hinder the poisoning of herbicides among the spray workers at oil palm plantation.

\section{MATERIAL AND METHODS}

A crossectional study was conducted between June until November 2018 on 326 sprayers with simple random sampling in 10 palm oil plantation using paraquat herbicides in East Kalimantan province of Indonesia. The level of pesticide poisoning was measured based on blood cholinesterase enzyme levels using a Tintometer kit (Lovibond 2000 with Comparator disk). Determination of poisoning category refers to the standards of the Indonesian Ministry of Health. ${ }^{24}$ The normal level of cholinesterase is between $75-100 \%$, while mild, moderate and severe poisoning category level of cholinesterase activity is between $50-75 \%, 25-75 \%$, and $0-25 \%$, respectively.

Data on age, working period and area of spray per day were collected by a direct interview. Rank Spearman test was applied to see the correlation between levels of cholinesterase enzyme and independent variables (distribution of age, working period, and spraying area per day) because the data do not normally distribute. The working period is the length of time since the respondent was active as a spray worker until the study took place. The spraying area in this study illustrates the duration of paraquat 
herbicide exposure to the spray workers.

\section{RESULTS AND DISCUSSION}

Table 1. shows the age of respondent, working period, spraying area per day, level of cholinesterase and level of poisoning. The most spray workers are at the age of $>26-34(31.9 \%)$. The spray workers of $76.1 \%$ have working experience of fewer than five years. The spray workers of $84 \%$ have spraying area per day of fewer than 4 hectares. Twenty-nine sprayers $(8.8 \%)$ had mild toxicity, and 298 sprayers had normal cholinesterase activity levels. The age $(p=0.000)$ and spraying area per day $(p=0.014)$ correlated significantly with the level of blood serum cholinesterase activity.

Table 1. Association between spray workers characteristics $(\mathrm{n}=326)$ and poisoning level of pesticides

\begin{tabular}{|c|c|c|c|}
\hline Spray worker characteristics and poisoning level & Number & $\%$ & Correlation* \\
\hline Age (years) & & & $p=0.000$ \\
\hline $19-26$ & 67 & 20.6 & \\
\hline$>26-34$ & 104 & 31.9 & \\
\hline$>34-41$ & 98 & 30.1 & \\
\hline$>41-48$ & 53 & 16.3 & \\
\hline$>48-61$ & 4 & 1.2 & \\
\hline \multicolumn{4}{|l|}{ Mean=33.8, sd=8.01, Min=19, Max=61, } \\
\hline Working period (years) & & & $p=0.067$ \\
\hline$<5$ & 248 & 76.1 & \\
\hline$\geq 5$ & 78 & 23.9 & \\
\hline \multicolumn{4}{|l|}{ Mean=3.5, sd=2.3, Min=1, Max=11 } \\
\hline Spraying area per day (hectare) & & & $p=0.014$ \\
\hline$<4$ & 274 & 84 & \\
\hline$\geq 4$ & 52 & 16 & \\
\hline \multicolumn{4}{|l|}{ Mean $=1.8, \mathrm{sd}=0.3, \operatorname{Min}=1, \operatorname{Max}=2$, } \\
\hline \multicolumn{4}{|l|}{ Level of poisoning** } \\
\hline Normal $(75 \%-100 \%)$ & 297 & 91.1 & \\
\hline Mild poisoning $(50 \%-75 \%)$ & 29 & 8.9 & \\
\hline Moderate poisoning $(5 \%-25 \%)$ & 0 & 0 & \\
\hline Severe poisoning $(0 \%-25 \%)$ & 0 & 0 & \\
\hline Mean $=1.08, \mathrm{sd}=0.2, \operatorname{Min}=1, \operatorname{Max}=2$ & & & \\
\hline
\end{tabular}

\section{Cholinesterase level of sprayers}

Herbicide poisoning prevalence among sprayers of palm oil plantation was found relatively low $(8.9 \%)$, while most sprayers had cholinesterase levels within normal limits $(91.1 \%)$. Although the prevalence of poisoning is still low the results of this study can serve as an early warning that there has been exposed and has caused health impact on sprayers. As noted earlier, paraquat herbicides are Class I pesticides because of its acute toxicity, delayed effects and lack of an antidote. ${ }^{25}$ The toxicity of paraquat is very high with mortality rates around $70-80 \%{ }^{26}$ The toxicity of paraquat is very high with mortality rates around 70 $-80 \% .{ }^{26}$ The average death rate caused by paraquat poisoning is about $60-80 \%$, where the majority of cases are moderate to severe. The hypoxic death is associated with pulmonary fibrosis. ${ }^{27}$

Cases of death and toxicity due to paraquat are very high and handling is still less effective. ${ }^{28}$ In other countries such as Korea, paraquat herbicides have been banned since 2012 because it has caused significant casualties $(60-70 \%$ of deaths are estimated to be associated with paraquat herbicide poisoning). Despite its low contribution but a ban on the use of paraquat herbicides have reduced the rate of death from herbicide poisoning ( $70 \%$ to $67 \%){ }^{29}$
Factors associated with the cholinesterase activity level

\section{Age of Sprayers}

This study showed that the age of the sprayers was associated with herbicide poisoning prevalence $(p=0.000)$. This result makes sense because the age of the worker illustrates the accumulation of exposure time and the condition of the ability of various body organs to respond to pesticide exposure. This result is consistent with the previous studies, which showed a significant correlation between the age of workers and cholinesterase activity level. The age of the worker is one of the risk factors of decreasing cholinesterase activity among Latino Farmworkers in Korea, ${ }^{29}$ North Carolina, ${ }^{30}$ Brazilia $^{31}$ and Malaysia. ${ }^{32,30}$

Age of sprayer is associated with blood cholinesterase activity level, where the elder sprayer had lower cholinesterase activity than the average of blood cholinesterase activity. The fact showed a prevalence of the pesticide poisoning among the spray workers, ${ }^{33}$ which could decrease organ functionality, such as liver and kidney, and further accumulation of toxins in the body. ${ }^{20}$ 


\section{Working period and level of cholinesterase}

The working period was not related to cholinesterase activity levels. This result was opposite to Ishak et al..$^{32}$ who reported that increasing age and long-term pesticide exposure could reduce acetylcholinesterase activity levels in pesticides user farmers. Two factors are suspected to be associated with this result, i.e. (i) the working period of the spray workers is mostly $(86 \%)$ less than 5 years, which reflects that the total exposure time to pesticides was low; and (ii) the age of the spray workers is mostly young ( $62 \%$ between $26-41$ years old), which their metabolizing and secreting organs (liver and kidney) are still in good capacity against pesticide exposure.

\section{Spraying area per day and level of the cholinesterase activity}

The spray area per day $\left(<4\right.$ ha.day $^{-1}$, and $\geq 4$ ha.day $\left.^{-1}\right)$ is associated with cholinesterase activity level $(p=0.014)$. These results showed that the greater spray area and the longer exposure time of spray workers against pesticide. In this study, there are other conditions that can aggravate the exposure, where all respondents work without using adequate respiratory protective equipment.

These results are consistent with the previous study, which showed that the duration and volume of pesticide exposure correlated with cholinesterase activity level significance. ${ }^{22,23}$ These results support the conclusion of previous research that the level of pesticide poisoning is associated with spraying time (duration) and spray dosage. The longer of spraying time or, the higher of pesticide dose will increase the prevalence of pesticide poisoning. . $^{33,34}$

The area of spraying in this study illustrates the duration of exposure to paraquat herbicide to sprayers. Spray area is divided into two categories: less than 4 hectares and more than 4 hectares per day. The results prove the area of spray per day associated The results of this study are consistent with the results of previous studies which concluded that the duration and volume of pesticide exposure correlated with cholinesterase level significance. ${ }^{22,23}$ These results support the conclusion of previous research that the level of pesticide poisoning is affected by long spray (duration) and spray dosage. The longer the spraying time and the higher the pesticide dose the higher the poisoning rate. ${ }^{12,34}$

\section{CONCLUSIONS}

About $8.9 \%$ of spray workers at palm oil plantation in East Kalimantan had undergone poisoning with low category regarding to the cholinesterase activity of blood serum level (SBChE) test. The age of spray workers $(p=0.000)$ and spraying area per day $(p=0.014)$ were associated with the SBChE level. The two factors are the important parameters, which have to be managed in order to prevent the level of paraquat poisoning getting worst. .

\section{ACKNOWLEDGEMENT}

The authors are very grateful to all the sprayers and directors of palm oil plantation companies participated in this study. This study received no funding support and the author declare that there is no conflict of interest.

\section{REFERENCES}

1. Aktar W, Sengupta D, Chowdhury A. Impact of pesticides use in agriculture: their benefits and hazards. Interdiscip Toxicol. 2009, 2(1):1-12.

2. Damalas CA, Eleftherohorinos IG. Pesticide exposure, safety issues, and risk assessment indicators. Int J Environ Res Public Health 2011, 8(5):1402-19.

3. Macfarlane E, Carey R, Keegel T, El-Zaemay S, Fritschi L. Dermal exposure associated with occupational end use of pesticides and the role of protective measures. Saf Health Work 2013, 4(3):136-41.

4. Ahmad R, Ahad K, Iqbal R, Muhammad A. Acute poisoning due to commercial pesticides in Multan. Pakistan Journal of Medical Sciences 2002, 18: 227-31.

5. Bjørling-poulsen M, Andersen HR, Grandjean P. Potential developmental neurotoxicity of pesticides used in Europe. Environ Heal. 2008, 7(50): $1-22$.

6. Hu R, Huang X, Huang J, Li Y, Zhang C, Yin Y, et al. Long- and short-term health effects of pesticide exposure: A cohort study from China. PLoS One 2015,10(6):1-13.

7. Salameh P. Respiratory diseases and pesticide exposure: a case-control study in Lebanon. J Epidemiol Community Heal. 2006, 60(3):256-61.

8. Hoppin JA, Umbach DM, London SJ, Henneberger PK, Kullman GJ, Alavanja MCR, et al. Pesticides and atopic and nonatopic asthma among farm women in the agricultural health study. Am J Respir Crit Care Med. 2008, 177(1):11-8.

9. Bretveld RW, Thomas CMG, Scheepers PTJ, Zielhuis GA, Roeleveld N. Pesticide exposure: the hormonal function of the female reproductive system disrupted? Reprod Biol Endocrinol. 2006, 4(30):1-14.

10. Mnif W, Hassine AIH, Bouaziz A, Bartegi A, Thomas O, Roig B. Effect of endocrine disruptor pesticides: A review. Int $\mathrm{J}$ Environ Res Public Health 2011, 8(6):2265-303.

11. Bassil KL, Vakil C, Sanborn M, Cole DC, Kaur JS, Kerr KJ, et al. Cancer health effects of pesticides. Can Fam Physician 2007, 53(10):1704-11.

12. Lu JL. Total pesticide exposure calculation among vegetable farmers in benguet, philippines. J Environ Public Health. 2009, 412054.

13. Kishi M, Hirschhorn N, Djajadisastra M, Satterlee LN, Strowman S, Dilts R. Relationship of pesticide spraying to signs and symptoms in Indonesian farmers. Scand J Work Environ Heal. 
1995, 21(2):124-33.

14. Departemen Kesehatan Republik Indonesia, Ditjen PPM \& PLP. Laporan program penyehatan lingkungan permukiman tahun 1995/1996. Jakarta; 1996.

15. Muslih AM, Zakaria WA, Kasymir E. Analysis of Affecting Factors on Lampung Province CPO Exports. JIAA. 2013, 1(2):92-7.

16. Dinas Pertanian Provinsi Kalimantan Timur. Komoditi Kelapa Sawit Kalimantan Timur. 2017.

17. Dinas Tenaga Kerja dan Transmigrasi Provinsi Kalimantan Timur. Rencana Tenaga Kerja Provinsi Kalimantan Timur Tahun 2014-2018. Samarinda; 2013.

18. Untung K. Impact of Integrated Pest Management to The Registration and Use of Pesticide in Indonesia. J Perlindungan Tanam Indones. 2004, $10(1): 1-7$.

19. Windarti I, Widayana IGE. Effect Paraquat Dichloride Herbicides Orally on the Stage of Esophagus Damage in Male Rats. Juke Unila 2015, 5(9):9-12.

20. Rahmawati YD, Martiana T. Pengaruh faktor karakteristik petani dan metode penyemprotan terhadap kadar kolinesterase. Indones J Occup Safety, Heal Environ. 2014, 1(1):85-94.

21. Vikey HA, Dossou F, Hountikpo H, Lawin H, Koudafoke A, Fayomi B, et al. Risk Factors of Pesticide Poisoning and Pesticide Users' Cholinesterase Levels in Cotton Production Areas: Glazoué and Savè Townships, in Central Republic of Benin. Environ Health Insights. 2017, 11(0):110.

22. Wilaiwan W, Baokumkong C, Siriwong W, Pidgunpai K. Cholinesterase Levels and Adverse Health Effects Among Rice Farmers Using Pesticides in Agricultural Areas, the Central of Thailand. Int J Manag Appl Sci. 2015, 1(9):27-30.

23. Nganchamung T, Robson M, Siriwong W. Association Between Blood Cholinesterase Activity, Organophosphate Pesticide Residues on Hands, and Health Effects. Rocz Panstw Zakl Hig. 2017, 68(2):175-83.

24. Departemen Kesehatan Republik Indonesia. Pemeriksaan Kholinesterase Darah dengan Tintometer Kit. Jakarta; 1992.

25. Watts M. Paraquat. Pestic Action Netw Asia Pacific 2011, 1-44.

26. Banday TH, Bashir S, Bhat S, Ashwin K, Praveen, Jagadeesh SG. Manifestation and Management of Paraquat Intoxiction. A deadly poison? IOSR J Dent Med Sci. 2013, 12(6):74-6.
27. Dinis-Oliveira RJ, Duarte JA, Sánchez-Navarro A, Remião F, Bastos ML, Carvalho F. Paraquat poisonings: Mechanisms of lung toxicity, clinical features, and treatment. Crit Rev Toxicol. 2008, 38(1):13-71.

28. Gawarammana IB, Buckley NA. Medical management of paraquat ingestion. $\mathrm{Br} \mathrm{J}$ Clin Pharmacol. 2011, 72(5):745-57.

29. Ko DR, Chung SP, You JS, Cho S, Park Y, Chun $\mathrm{B}$, et al. Effects of paraquat ban on herbicide poisoning-related mortality. Yonsei Med J. 2017, 58(4):859-66.

30. Quandt SA, Chen H, Grzywacz JG, Vallejos QM, Galvan L, Arcury TA. Depression and its association with pesticide exposure across the agricultural season among Latino farmworkers in North Carolina. Environ Health Perspect. 2010, 118(5):635-9.

31. Nerilo SB, Martins FA, Nerilo LB, Salvadego VEC, Endo RY, Rocha GHO, et al. Pesticide use and cholinesterase inhibition in small-scale agricultural workers in southern Brazil. Brazilian J Pharm Sci. 2014, 50(4):783-92.

32. Ishak I, Lubis SH, Hamid ZA, Mohammad N. Acetylcholinesterase Levels in Farmers Exposed to Pesticides in Malaysia. Int J Appl Biol Pharm Technol. 2015, 6(4):106-12.

34. Dosemeci M, Alavanja MC., Rowland AS, Mage D, Zahm S., Rothman N, et al. A Quantitative Approach for Estimating Exposure to Pesticides in the Agricultural Health Study. Ann Occup Hyg. 2002, 46; 245-60. 